\title{
Pengaruh Imbangan Energi dan Protein Serta Kepadatan Kandang Terhadap Penampilan Ayam Pedaging
}

\section{The Influence of Energy - Protein Balance and Cage Density to the Broiler Performance}

\author{
H. Silondae* dan D. Polakitan \\ Balai Pengkajian Teknologi Pertanian Sulawesi Utara \\ *E-mail: hasrianti_silondae@yahoo.com \\ (Diterima: 23 Mei 2018; Disetujui: 25 Juli 2018)
}

\begin{abstract}
ABSTRAK
Masalah imbangan energi-protein dalam ransum serta kepadatan kandang yang berbeda merupakan bahan kajian yang perlu dilakukan dalam upaya perbaikan penampilan ayam broiler. Penelitian ini bertujuan untuk mengetahui pengaruh imbangan energi dan protein serta kepadatan kandang terhadap penampilan ayam pedaging. Metode percobaan menggunakan rancangan acak lengkap (RAL) pola faktorial 3x2 dengan empat ulangan. Perlakuan terdiri atas dua faktor, dimana faktor pertama adalah adalah kepadatan ternak (A) terdiri atas tiga taraf perlakuan yaitu 4 ekor $/ \mathrm{m}^{2}\left(\mathrm{~A}_{1}\right), 8$ ekor $/ \mathrm{m}^{2}\left(\mathrm{~A}_{2}\right)$, dan $12 \mathrm{ekor} / \mathrm{m}^{2}\left(\mathrm{~A}_{3}\right)$. Faktor kedua adalah imbangan energi dan protein (B), terdiri atas dua taraf perlakuan yaitu: $2900 \mathrm{kkal} / \mathrm{kg}: 22 \% \mathrm{PK}$ (B), dan $3100 \mathrm{kkal} / \mathrm{kg}: 19 \% \mathrm{PK}\left(\mathrm{B}_{2}\right)$. Dari hasil penelitian diperoleh bahwa perlakuan $\mathrm{A}_{1} \mathrm{~B}_{1}: 4 \mathrm{ekor} / \mathrm{m}^{2}-2900$ $\mathrm{kkal} / \mathrm{kg}(\mathrm{EM}): 22 \%(\mathrm{PK})$ berpengaruh nyata terhadap nilai $\mathrm{KRH}, \mathrm{PBBH}$, konversi ransum, dan persentase karkas.
\end{abstract}

Kata kunci: broiler, energi, kepadatan kandang, protein

\section{ABSTRACT}

The problem of energy-protein balance in the rations and the density of different cages is a study material that needs to be done in an effort to improve the appearance of broiler chickens. This experiment research aims to determine the effect of energy and protein balance and cage density on broiler performance. The experimental method used by completely randomized design (CRD) 3x2 factorial pattern with four replications. The treatment consisted of two factors, where the first factor was the density of livestock (A) consisting of three treatment levels $4 \mathrm{birds} / \mathrm{m}^{2}$ (A1), $8 \mathrm{birds} / \mathrm{m}^{2}$ (A2), and $12 \mathrm{birds} / \mathrm{m}^{2}$ (A3). The second factor was the energy and protein balance (B), consisting of two treatment levels: $2,900 \mathrm{kcal} / \mathrm{kg}: 22 \%$ $P K$ (B1), and 3,100 kcal $/ \mathrm{kg}: 19 \%$ PK (B2). The result showed that the treatment of A1B1: $4 \mathrm{birds} / \mathrm{m}^{2}-$ 2,900 kkal/kg (EM): $22 \%(P K)$ was the best effect on daily ration consumption, daily weight gain, ration conversion, and carcass percentage.

Keywords: broiler, density of the cage, energy, protein

\section{PENDAHULUAN}

Perkembangan usaha ayam pedaging di Indonesia cukup pesat karena sifat genetik yang baik dalam menghasilkan daging lebih cepat dari jenis ternak lain. Ayam broiler pertumbuhannya sangat cepat dengan bobot $1,5 \mathrm{~kg}$ sampai umur 30 hari (Rahayu et al., 2011). Broiler memiliki sifat unggul antara lain proses pertumbuhan yang cepat, sehingga masa panen bisa lebih pendek, efisien dalam konsumsi ransum, menghasilkan daging yang lunak dengan kulit yang licin (Risnajati, 2012). Prestasi pertumbuhan broiler ini tentu saja dicapai dengan usaha perbaikan melalui rekayasa genetik, perbaikan tata laksana pemeliharaan dan perbaikan kualitas ransum, sehingga dapat diperoleh hasil yang baik. Imbangan energi dan protein dalam ransum merupakan faktor utama perbaikan tingkat pertumbuhan broiler. Salah satu faktor penting yang harus diperhatikan dalam pembuatan 
ransum unggas adalah kandungan energinya disamping protein sebagai faktor penting dalam pembuatan jaringan tubuh.

Penyusunan ransum ayam broiler harus memperhatikan unsur energi dan protein. Ayam broiler umur 0-3 minggu dalam ransumnya mengandung protein sebesar $23 \%$ dan energi metabolis $3.200 \mathrm{kkal} / \mathrm{kg}$ (NRC, 1994). Kandungan protein berfungsi untuk pertumbuhan dan pembentukan tulang. Sedangkan ketersediaan energi untuk menunjang aktivitas ayam dan tujuan produksi. Penelitian mengenai imbangan protein dan energi terus dilakukan oleh para pakar nutrisi dan produksi unggas. Soeharsono (1976) mengungkapkan respon broiler terhadap berbagai kondisi lingkungan dan perbandingan kandungan proteinenergi dalam ransum. Rosebrough dan Steele (1985) meneliti pengaruh perbedaan level protein terhadap komposisi tubuh dan proses lipogenesis. Sizemore dan Siegel (1993) menitikberatkan kajiannya mengenai pengaruh imbangan energi-protein rasio terhadap broiler betina. Hidalgo et al. (2004) juga turut menyumbankan hasil penelitiannya mengenai respon prestasi kinerja broiler berdasarkan imbangan energi metabolis dan protein kasar.

Pada broiler kadar lemak karkas ditingkatkan pada akhir penggemukan dengan jalan mengurangi kadar protein ransum sedikit dibawah yang dibutuhkan untuk laju pertumbuhan maksimum dan meningkatkan energi ransum sampai pada suatu tingkatan mendekati tingkatan energi tertinggi. Broiler yang berumur tujuh sampai delapan minggu mengkomsumsi lebih banyak energi dari pada yang dibutuhkan untuk pertumbuhan, disebabkan karena energi ransum yang sangat tinggi dan sebagian karena defisiensi ringan dari protein. Kelebihan energi tersebut akan dirubah kedalam lemak tubuh disamping menghasilkan tubuh akhir (body finish) yang dikehendaki untuk dipasarkan (Anggorodi, 1984). Hal lain yang perlu mendapat perhatian adalah kepadatan kandang tidak terlalu padat karena akan berakibat pada performa ayam itu sendiri seperti konsumsi ransum menurun disebabkan kesempatan makan berkurang, sehingga pertumbuhan tidak tercapai secara optimal, serta kanibalisme meningkat yang menambah jumlah kematian ayam. Kandang sistem litter dengan padat ternak menimbulkan bau busuk karena meningkatnya kadar gas ammonia $\left(\mathrm{NH}_{3}\right)$. Kadar ammonia sebesar $50 \%$ akan menurunkan $8 \%$ berat badan ayam umur 7 minggu. Kondisi litter yang basah menimbulkan penyakit snot, cacingan, dan lain sebagainya. Keseimbangan energi dan protein dalam ransum sangat penting dalam setiap tahapan pertumbuhan broiler, demikian pula pemberian lemak harus berimbang antara starter dan finisher yaitu masing-masing dalam ransum sebesar 7\% dan 6\% (Djannah, 1985).

\section{METODE}

Penelitian ini dilaksanakan di Kebun Percobaan Pandu, Kecamatan Wori Kabupaten Minahasa Utara, pada bulan Februari sampai bulan Juni 2015. Materi penelitian menggunakan DOC ayam pedaging strain CP 707. Bahan kandang menggunakan bambu, atap rumbia, dan kayu. Adapun peralatan lainnya seperti timbangan, tempat minum, tempat pakan, terpal, lampu, alat tulis menulis, sekam, koran, obat-obatan dan lain-lain disediakan di dalam kandang. Sistem kandang panggung percobaan dibagi 24 unit percobaan masing-masing berukuran panjang $100 \mathrm{~cm}$, lebar $100 \mathrm{~cm}$ dan tinggi $50 \mathrm{~cm}$. Setiap plot percobaan kandang dilengkapi dengan wadah pakan dan galon tenteng tipe manual. Pakan yang digunakan adalah jagung kuning, konsentrat ayam pedaging, bungkil kelapa, dedak halus, tepung ikan, dan topmix (Tabel 1). Pemberian minum dilakukan bersamaan dengan pemberian pakan.

\section{Variabel Penelitian}

Variabel penelitian yang diamati antara lain konsumsi ransum harian, pertambahan bobot badan harian, konversi ransum, persentase bobot karkas, dan mortalitas. 
Tabel 1. Kandungan nutrisi dan energi metabolis pakan

\begin{tabular}{llcccc}
\hline No & Bahan pakan & $\begin{array}{c}\text { Protein } \\
(\%)\end{array}$ & $\begin{array}{c}\text { Lemak } \\
(\%)\end{array}$ & $\begin{array}{c}\text { Serat kasar } \\
(\%)\end{array}$ & $\begin{array}{c}\text { Energi metabolis } \\
(\mathrm{kkal} / \mathrm{kg})\end{array}$ \\
\hline 1 & Jagung Kuning & 9 & 3,9 & 2.2 & 3360 \\
2 & Konsentrat* & 36 & $3,0-8,0$ & 8 & 2100 \\
3 & Bungkil kelapa & 20.5 & 1,8 & 10.3 & 3050 \\
4 & Dedak Halus & 13.6 & 4,0 & 8 & 2740 \\
5 & Tepung ikan & 61.8 & 4,0 & 0.6 & 2910 \\
6 & Premix/Topmix & & & & \\
\hline
\end{tabular}

Sumber: Rahayu et al., 2011; *SNI 2009

\section{Analisa Data}

Rancangan percobaan dalam penelitian menggunakan rancangan acak lengkap (RAL) pola faktorial $3 \times 2$ dengan empat kali ulangan. Perlakuan terdiri atas dua faktor, dimana faktor pertama adalah adalah kepadatan ternak (A) terdiri atas tiga taraf perlakuan yaitu 4 ekor/m2 (A1), 8 ekor/m2 (A2), dan 12 ekor/m2 (A3). Faktor kedua adalah imbangan energi dan protein (B), terdiri atas dua taraf perlakuan yaitu: $2900 \mathrm{kkal} / \mathrm{kg}$ : 22\% PK (B1), dan $3100 \mathrm{kkal} / \mathrm{kg}$ : 19\% PK (B2), dengan demikian diperoleh 6 perlakuan dan 4 ulangan sehingga terdapat 24 unit percobaan.

Kombinasi perlakuan antara lain:

a). $A_{1} B_{1}: 4$ ekor $/ \mathrm{m}^{2}-2900 \mathrm{kkal} / \mathrm{kg}(\mathrm{EM}): 22$ $\%(\mathrm{PK})$

b). $A_{1} B_{2}: 4$ ekor $/ \mathrm{m}-3100 \mathrm{kkal} / \mathrm{kg}(\mathrm{EM}): 19$ $\%(\mathrm{PK})$

c). $\mathrm{A}_{2} \mathrm{~B}_{1}: 8 \mathrm{ekor} / \mathrm{m}^{2}-2900 \mathrm{kkal} / \mathrm{kg}(\mathrm{EM}): 22$ $\%(\mathrm{PK})$

d). $\mathrm{A}_{2} \mathrm{~B}_{2}: 8 \mathrm{ekor} / \mathrm{m}^{2}-3100 \mathrm{kkal} / \mathrm{kg}(\mathrm{EM}): 19$ $\%(\mathrm{PK})$

e). $A_{3} B_{1}: 12$ ekor $/ \mathrm{m}^{2}-2900 \mathrm{kkal} / \mathrm{kg}(\mathrm{EM})$ : $22 \%(\mathrm{PK})$

f). $A_{3} B_{2}: 12 \mathrm{ekor} / \mathrm{m}^{2}-3100 \mathrm{kkal} / \mathrm{kg}(\mathrm{EM})$ : $19 \%$ (PK)

Analisa data menggunakan sidik ragam dan uji $F$, bila terdapat perlakuan yang berbeda nyata dilakukan analisa lanjutan dengan uji beda nyata terkecil (Steel and Torrie,1995). Penyusunan ransum berdasarkan kandungan nutriennya dapat dilihat pada Tabel 1 .

\section{HASIL DAN PEMBAHASAN}

Hasil uji pengaruh imbangan energi dan protein terhadap performa ayam pedaging disajikan pada Tabel 2.

\section{Konsumsi Ransum Harian}

Berdasarkan analisa statistik, perlakuan imbangan energi protein dan kepadatan kandang berpengaruh nyata terhadap konsumsi ransum harian ayam pedaging. Diketahui konsumsi ransum ayam pedaging menunjukkan perbedaan yang signifikan antara perlakuan (Tabel 2), dengan konsumsi ransum paling rendah terdapat pada perlakuan $\mathrm{A}_{1} \mathrm{~B}_{1}$ (4 ekor $/ \mathrm{m}^{2}-2900 \mathrm{kkal} / \mathrm{kg}(\mathrm{EM}): 22$ $\%(\mathrm{PK})$, sebesar 594,11, $\mathrm{A}_{2} \mathrm{~B}_{2}$ dan $\mathrm{A}_{2} \mathrm{~B}_{1}$ sebesar 861,11 dan 964,71. Sedangkan $A_{1} B_{2}$, $\mathrm{A}_{3} \mathrm{~B}_{1}$ dan $\mathrm{A}_{3} \mathrm{~B}_{2}$ menunjukkan perbedaan yang tidak signifikan. Secara numerik, perlakuan $\mathrm{A}_{1} \mathrm{~B}_{2}$ (4 ekor $/ \mathrm{m}^{2}$ - $3100 \mathrm{kkal} / \mathrm{kg}(\mathrm{EM}): 19$ $\%(\mathrm{PK})$ tidak berbeda jauh lebih tinggi dengan kepadatan kandang 12 ekor/m. Tahapan pertumbuhan ayam turut dipengaruhi oleh kandungan energi rasio dalam ransum. Apabila kandungan energinya rendah maka ayam akan makan lebih banyak begitupun sebaliknya. Soeharsono (1976) menyarankan besaran energi rasio untuk broiler fase finisher sebesar $3000 \mathrm{kkal} / \mathrm{kg}$ dan protein $22 \%$, sementara Yuwananta (2004), menambahkan sampai $3200 \mathrm{kkal} / \mathrm{kg}$ dalam ransum.

\section{Pertambahan Bobot Badan Harian}

Kepadatan ternak dalam setiap plot percobaan menyebabkan tingkat persaingan makan yang berbeda pula. Kepadatan ternak 
Tabel 2. Pengaruh imbangan energi dan protein serta kepadatan kandang terhadap penampilan ayam pedaging

\begin{tabular}{cccccc}
\hline Perlakuan & $\begin{array}{c}\text { Konsumsi } \\
\text { Ransum } \\
\text { Harian } \\
(\mathrm{g} / \text { ekor) }\end{array}$ & $\begin{array}{c}\text { Pertambahan } \\
\text { Bobot Badan } \\
\text { Harian } \\
\text { (g/ekor) }\end{array}$ & $\begin{array}{c}\text { Konversi } \\
\text { ransum }\end{array}$ & $\begin{array}{c}\text { Persentase } \\
\text { Bobot karkas } \\
(\%)\end{array}$ & $\begin{array}{c}\text { Mortalitas } \\
\text { (ekor) }\end{array}$ \\
\hline $\mathrm{A}_{1} \mathrm{~B}_{1}$ & $594,14^{\mathrm{c}}$ & 202,27 & $0,96^{\mathrm{c}}$ & 85 & - \\
$\mathrm{A}_{1} \mathrm{~B}_{2}$ & $1569,82^{\mathrm{a}}$ & 161,89 & $2,60^{\mathrm{a}}$ & 80 & 1 \\
$\mathrm{~A}_{2} \mathrm{~B}_{1}$ & $964,71^{\mathrm{b}}$ & 202,80 & $1,59^{\mathrm{b}}$ & 83 & - \\
$\mathrm{A}_{2} \mathrm{~B}_{2}$ & $861,11^{\mathrm{b}}$ & 186,08 & $1,46^{\mathrm{b}}$ & 83 & - \\
$\mathrm{A}_{3} \mathrm{~B}_{1}$ & $1459,36^{\mathrm{a}}$ & 189,76 & $2,52^{\mathrm{a}}$ & 84 & - \\
$\mathrm{A}_{3} \mathrm{~B}_{2}$ & $1397,93^{\mathrm{a}}$ & 227,71 & $2,48^{\mathrm{a}}$ & 84 & - \\
\hline
\end{tabular}

Keterangan: Huruf yang berbeda menunjukkan perbedaan nyata antar perlakuan $(\mathrm{P}<0,5)$

yang tinggi menunjukkan pertambahan bobot badan harian yang tidak signifikan. Meskipun jumlah ransum yang diberikan sesuai dengan kebutuhan ayam setiap hari akan tetapi tingkat kepadatan ternak menyebabkan perbedaan respon dan pola konsumsi pakan. Hasil Anova (Tabel 2) memberikan gambaran bahwa imbangan dan energi protein tidak berpengaruh signifikan terhadap variasi pertambahan bobot badan harian ayam ras pedaging. Diduga perbedaan respon ini disebabkan rasio jantan dan betina di dalam plot percobaan sehingga menyebabkan nilai KRH,PBBH, Konversi dan Karkas tidak sejalan. Ada perlakuan yang memberikan nilai KRH yang kecil, PBBH sedang, Konversi Ransum kecil, akan tetapi, karkas tinggi $\left(\mathrm{A}_{1} \mathrm{~B}_{1}\right)$ demikan pula perlakuan lainnya. Dikatakan bahwa pertumbuhan jantan lebih cepat ketimbang ayam betina dikarenakan jantan lebih efisien dalam mengubah ransum menjadi daging. Meski demikian, secara numerik perlakuan kepadatan ternak 4 ekor dan 8 ekor masih memberikan hasil yang optimal bagi Konsumsi Ransum Harian, PBBH, Konversi Ransum, dan Persentase Karkas.

\section{Konversi ransum}

Hasil uji satistik terhadap nilai konversi ransum menunjukkan perbedaan yang signifikan antara perlakuan. Nilai konversi ransum paling rendah terdapat perlakuan
$\mathrm{A}_{1} \mathrm{~B}_{1}(0,91)$ dan paling tinggi terdapat pada perlakuan $A_{1} B_{2}(2,60)$. Hal ini memberikan indikasi bahwa ransum dengan kandungan energi $2900 \mathrm{kkal} / \mathrm{kg}$ dan protein $22 \%$ serta kepadatan kandang 4 ekor/m2 mengandung kualitas ransum yang baik dalam menghasilkan bobot badan persatuan berat. Biaya pakan dalam usaha ternak ayam mencapai $70-80 \%$ dari biaya produksi total, sehingga secara ekonomis keuntungan yang diperoleh sangat ditentukan oleh biaya pakan tersebut. Biaya pakan yang dikeluarkan diharapkan dapat terserap secara optimal oleh ayam untuk meningkatkan pertumbuhan bobot badan, sehingga dapat diperoleh nilai FCR yang rendah (Fadilah, 2005). Disusul perlakuan $\mathrm{A}_{2} \mathrm{~B}_{1}$ dan $\mathrm{A}_{2} \mathrm{~B}_{2}$ dengan konversi ransum 1,59 dan 1,46. Sedangkan nilai konversi ransum tertinggi terdapat pada perlakuan $\mathrm{A}_{1} \mathrm{~B}_{2}$, diduga ransum dengan kandungan energi tinggi dan protein rendah turut menyebabkan konsumsi ransum yang tinggi oleh ayam yang masih dalam tahapan pertumbuhan tersebut. Disusul perlakuan $\mathrm{A}_{3} \mathrm{~B}_{1}$ dan $\mathrm{A}_{3} \mathrm{~B}_{2}$ masing-masing sebesar 2,52 dan 2,48. Kepadatan ternak sangat berpengaruh terhadap nilai konversi ransum karena semakin banyak ransum yang dihabiskan ayam dalam meningkatkan bobot badan per satuan berat. Beberapa faktor yang mempengaruhi besar kecilnya angka konversi ransum antara lain faktor genetik, sanitasi, kualitas air, jenis ternak serta manajemen pemeliharaannya khususnya 
tingkat kepadatan kandang (Rafian, 2003). Nilai konversi ransum pada semua perlakuan masih tahap wajar sesuai pernyataan Scott et al. (1982) bahwa konversi ransum ayam broiler selama 6 minggu pertama berkisar 1,72,0. Sedangkan Santoso (2002), menjelaskan bahwa konversi pakan pada ayam broiler selama lima minggu pada kandang litter sebesar 1,6. Konversi pakan ayam broiler strain CP 707 yang dipelihara pada suhu nyaman pada umur lima minggu adalah 1,62. Menurut Lesson (2000), menyatakan bahwa semakin dewasa ayam maka nilai konversi pakan akan semakin besar. Oleh karena itu, penyusunan ransum berdasarkan imbangan energi dan protein rasio diharapkan dapat mempengaruhi pertumbuhan ayam secara optimal sehingga mendapat keuntungan.

\section{Persentase Karkas}

Perlakuan imbangan energi-protein tidak berpengaruh nyata terhadap persentase bobot karkas. Meski secara numerik, persentase bobot karkas berbeda dengan kisaran yang direkomendasikan oleh Rasyaf (1995) bahwa persentase karkas broiler umur 5-6 minggu adalah $65-70 \%$ dari bobot akhir. Diketahui bahwa perlakuan A1B1 (4 ekor/m2 - $2900 \mathrm{kkal} / \mathrm{kg}$ (EM) : $22 \%(\mathrm{PK})$, diperoleh persentase tertinggi sebesar $85 \%$ dan yang terendah adalah A1B2 sebesar $80 \%$. Diduga bahwa perlakuan berpengaruh tidak nyata terhadap bobot akhir sehingga tidak berpengaruh nyata pula terhadap persentase karkas. Diketahui persentase karkas merupakan perbandingan antara bobot karkas dengan bobot akhir. Mountney (1976) menyatakan bahwa lemak dan jeroan merupakan hasil ikutan yang tidak dihitung dalam persentase karkas. Kandungan lemak yang tinggi akan menyebabkan rendahnya persentase karkas.

\section{Mortalitas}

Dari hasil penelitian, jumlah ayam yang mati hanya 1 ekor (1\%). Hal ini memberikan gambaran bahwa selama penelitian pola pemeliharaan dilakukan dengan baik dan mengikuti prosedur pemeliharaan yang telah ditetapkan antara lain kandang terbuat dari bahan-bahan yang tahan lama, sehingga kandang dapat menyediakan lingkungan yang nyaman, terhindar dari cekaman (stress) yang dapat memudahkan wabah penyakit dan berakibat pada kematian. Angka mortalitas $3-5 \%$ masih dianggap wajar dalam usaha pemeliharaan ayam pedaging (broiler). Tentu saja dibutuhkan strategi yang dapat menekan angka mortalitas tersebut seperti sistem manajemen dan tata kelola yang baik, bibit unggul, memberikan ransum yang berkualitas dan dalam jumlah yang memadai, hingga pemberian vaksin dan obat-obatan sesuai dosis yang dibutuhkan.

\section{KESIMPULAN}

Dari hasil penelitian diperoleh bahwa perlakuan $\mathrm{A}_{1} \mathrm{~B}_{1}: 4 \mathrm{ekor} / \mathrm{m}^{2}-2900 \mathrm{kkal} / \mathrm{kg}$ (EM) : $22 \%(\mathrm{PK})$ memberikan pengaruh nyata lebih baik terhadap konsumsi ransum harian, pertambahan bobot harian, konversi ransum, dan persentase karkas. Angka mortalitas hanya $1 \%$ menunjukkan manajemen pemeliharaan selama penelitian berlangsung baik.

\section{UCAPAN TERIMA KASIH}

Penulis menyampaikan terima kasih kepada bapak Ir. Ibrahim Erik Malia, M.Agr yang telah meluangkan waktu berdiskusi mengenai penulisan makalah dan beberapa tekhnisi di Kebun Percobaan Pandu BPTP Sulawesi Utara yang turut berkontribusi menyukseskan penelitian ini.

\section{DAFTAR PUSTAKA}

Anggorodi, R. 1984. Ilmu Makanan Ternak Dasar. PT. Gramedia. Jakarta

Fadilah, R. 2005. Panduan Mengelola Peternakan Ayam Broiler Komersial. Agromedia Pustaka. Jakarta.

Hidalgo, M.A., W.A. Dozier., A.J. Davis., and R.W. Gordon. 2004. Live Performance 
and Meat Yield Response to Progressive Concentrations of Dietary Energy Maintained at A Constant Metabolizable Energy to Crude Protein Ratio. J. appl. Poult. Res. 13:319-327.

Lesson, S. 2000. Feed Efficiency Still A Useful Measure of Broilers Performance. Department Animal and Poultry Science. University of Guelph. Ontario.

Mountney, G.J. 1976. Poultry Product Technology 2nd Ed. The Avi Publishing Co.Inc. Westport. Conecticut.

Nutrient Requirements of Poultry. 2005. National Research Council (NRC). National Academy of Sciences. USA.

Rasyaf, M. 1995. Beternak Ayam Pedaging. PT. Penebar Swaday. Jakarta.

Rosebrough, R.W. and N.C. Steele. 1985. Energy and Protein Relations in The Broiler Effect of Protein Levels and Feeding Regimes on Growth Body Composition and In Vitro Lipogenesis in Broiler Chickens. Poult. Sci. 64:119126.

Rahayu, I., Sudaryani, T., dan Santosa, H. 2011. Panduan Lengkap Ayam. PT. Penebar Swadaya. Jakarta.

Risnajati, D. 2012. Perbandingan Bobot Akhir, Bobot Karkas dan Persentase Karkas Berbagai Strain Broiler. Sains
Peternakan. 10:11-14.

Rafian, A. 2003. Penampilan Ayam Broiler dan Komposisi Kimia Karkas Dengan Perlakuan Pembatasan Konsumsi Energi Pada Awal Fase Starter. Skripsi Fakultas Peternakan. Universitas Gajah Mada. Yogyakarta.

Steel, R.G.D and J.H. Torrie. 1995. Prinsip dan Prosedur Statistika: Suatu Pendekatan Biometrik. Gramedia. Jakarta.

Sizemore, F.G., and H.S. Siegel. 1993. Growth, Feed Conversion, and Carcass Composition in Females of Four Broiler Crosses Fed Starter Diets With Different Energy Levels and Energy to CP Ratios. Poult. Sci. 72:2216-2228.

Soeharsono. 1976. Respons Broiler Terhadap Berbagai Kondisi Lingkungan. Disertasi. UNPAD. Bandung.

Scott, M.L., M.C. Nesheim, and R.J. Young. 1982. Nutrition of Chicken. Third Edition. Ithaca, New York: M.L. Scott and Associates.

Santoso, U. 2002. Pengaruh Tipe Kandang dan Pembatasan Pakan di Awal Pertumbuhan Terhadap Performans dan Penimbunan Lemak Pada Ayam Pedaging Unsexed. JITV. 7:84-89.

Yuwananta, T. 2004. Dasar Ternak Unggas. Kanisius. Yogyakarta. 